\title{
PRODUCT STEWARDSHIP, ANIMAL WELFARE AND REGULATORY TOXICOLOGY CONSTRAINTS ON VERTEBRATE PESTICIDES
}

\author{
C.T. EASON ${ }^{1}$, M. WICKSTROM ${ }^{1}$ \\ and N. GREGORY ${ }^{2}$
}

\author{
${ }^{1}$ Landcare Research, PO Box 69, Lincoln, New Zealand \\ ${ }^{2}$ Department of Veterinary Sciences, Private Bag 11 222, \\ Massey University, Palmerston North, New Zealand
}

\begin{abstract}
Increasing regulatory and product safety standards along with the enhanced expectations of todays consumers have influenced the manner in which new pesticides are researched, developed and marketed. Potential new pesticides and older compounds subject to re-evaluation, face everrising standards in product efficacy, toxicology and environmental risk assessment. Vertebrate pesticides are no exception to this worldwide phenomenon and in this paper we review, using possum control in New Zealand as a case-study, some of the factors that are likely to influence the future use of toxicants in this field.
\end{abstract}

Keywords: Vertebrate pesticides, possum control, quality control, humane, registration

\section{INTRODUCTION}

All pesticides, whether they be the more commonly used and extensive range of compounds classified as herbicides, insecticides, or fungicides, or the small number of toxicants in the vertebrate pesticide group require product efficacy data coupled with a regulatory toxicology database, so that human health and environmental risks can be evaluated. Laboratory based regulatory toxicology studies need to be supplemented by field trials, initially to support registration, and subsequently for post-registration monitoring.

All OECD countries are cooperating in a review of the databases for agrochemicals registered before 1980 and the New Zealand Pesticide Board endorses this initiative. The Pesticide Board has summarised the criteria for selecting older compounds for reassessment as follows: the age of existing database, the extent of the use, operator hazards, animal welfare, and environmental impacts (Agcarm Review, March 1995, July 1996).

On the basis of these criteria, the vertebrate pesticides used for possum (Trichosurus vulpecula) control are prime candidates for re-assessment for the following reasons. The databases on these compounds, particularly the older toxicants such as sodium monofluoroacetate (1080), cyanide, phosphorus, and pindone are becoming antiquated. For example, 1080 has been registered in New Zealand since 1954 when quite different and comparatively naive risk assessment procedures were in place. Pesticides for possum control are applied over large areas of land in New Zealand, in contrast to overseas where their use is frequently restricted to targeting commensal rodents around homes, farm buildings and factories (Colvin et al. 1991). These compounds are extremely toxic to mammals, hence minimizing risk to the health of those involved directly in the manufacture and distribution of baits requires sustained scrutiny. Vertebrate pesticides have unique animal welfare concerns, since their target species are sentient mammals. Finally the controversial nature of the environmental impact associated with these toxicants is highlighted by on-going research and monitoring of effects on non-target species and environmental fate (Spurr 1994). 
The newly formed Environmental Risk Management Authority (ERMA) will be assuming responsibility for pesticide registration in New Zealand in the near future. This regulatory body is likely to be even more rigorous in their risk assessment procedures than the Pesticide Board, especially as the new Hazardous Substances and New Organisms (HSNO) Act is implemented. The new Act puts special emphasis on safeguarding the life-supporting capacity of air, water, soil and ecosystems.

\section{WHY ARE VERTEBRATE PESTICIDES USED FOR POSSUM CONTROL?}

The Australian brushtail possum is considered the most damaging animal pest in New Zealand. Possums are responsible for the destruction or modification of large tracts of native forests (Cowan 1991) and they are the primary wild animal vector of bovine tuberculosis (Tb) in New Zealand (Livingstone 1994).

Although there is wide public acceptance for large-scale control of possum populations, it is with the caveat that such killing be humane and have minimal adverse effects on nontarget species. The potential options available for killing possums include shooting, trapping and poisoning using vertebrate pesticides. For the large-scale possum control frequently required over remote, rugged, and forested country, the only available costeffective option is the use of toxic baits.

\section{HOW ARE VERTEBRATE PESTICIDES USED FOR POSSUM CONTROL?}

Toxicants registered for use for possum control in New Zealand are 1080, cyanide, phosphorus, pindone (Pest Off), brodifacoum (Talon) and cholecalciferol (CAMPAIGN). The most extensively used pesticide for possum control is 1080. It is incorporated in cereal pellets or applied to carrots for aerial sowing and for use in bait stations. Phosphorus, cyanide, and 1080 are also used in pastes for ground control. Brodifacoum, pindone and cholecalciferol are incorporated into cereal baits and only used in bait stations. Cyanide has recently been encapsulated in a small pellet (Feratox), for bait station use, as an alternative to the traditional paste, in an effort to improve the effectiveness and reduce the hazard associated with this toxin.

The use of pesticides to control possum populations is expected to increase over the next 10-15 years. Therefore, it is both prudent and timely to investigate issues such as product stewardship, animal welfare concerns and the adequacy of the regulatory toxicology databases for these agents.

\section{PRODUCT STEWARDSHIP}

Key principles of product stewardship, include:

- making health, safety, and environmental considerations a priority;

- developing and implementing appropriate actions to minimise risk;

- maintaining a knowledge base to assess potential adverse effects of products and product uses (Weiler et al. 1993).

It is important that both manufacturers and users of toxic baits for possum control are familiar with the principles of product stewardship and have in place quality assurance programmes to minimise the risks associated with the use of these highly toxic agents. The "risk" of any vertebrate pesticide to human health, livestock or non-target wildlife is determined by a combination of the innate toxicity of the product itself (hazard), and the potential for exposure. Lack of quality assurance procedures and product stewardship in possum control dramatically increases the exposure component of this risk equation, and can result in:

- unacceptable non-target bird deaths during possum control with aerially sown 1080 baits;

- inadvertent livestock death, with subsequent litigation to recover losses;

- risk to humans manufacturing baits and handling baits in the field.

These unacceptable risks to human and environmental health are compounded by 
wasted bait, time, and money, the need for repeated poisoning operations, and increased public resistance to possum control. It is unsatisfactory to note that, in 1997, 43 years after 1080 was first used in New Zealand, bait quality (whether it be commercial manufactured cereal bait or carrot bait prepared in the field) still remains a contentious issue. Practices that do not meet high safety standards for the protection of human health and the environment must be discontinued immediately if public acceptance of vertebrate pesticide use is to be retained.

The knowledge base for environmental fate and non-target effects for these products, particularly 1080, is relatively strong (Seawright and Eason 1994: Eisler 1995; Easonet al. 1994; Eason and Spurr 1995; Spurr 1994). Hence, in the following two sections we have focused our attention on animal welfare and regulatory toxicology, as these are two important areas where the database is deficient.

\section{ANIMAL WELFARE}

International perceptions of the possum control methods used in New Zealand may have significant implications for trade. There is a delicate balance between reducing $\mathrm{Tb}$ to sustain exports and killing possums in an acceptable manner. Current and future control methods will be judged by increasingly critical home and overseas trading partners and consumers (Williams 1994). The Ministry for Agriculture (MAF) has continued to emphasise the need to 'reinforce national and international recognition of New Zealand's healthy and humane image' with regard to the treatment of animals (MAF 1993; 1995). These intentions form the basis for setting the strategic directions for MAF to the year 2000, but little research is being done to evaluate how humane vertebrate pest control techniques are.

In 1993, the Animal Welfare Advisory Committee (AWAC) recommended the withdrawal of phosphorus by December 1994 (AWAC 1994), and last year expressed further concerns about its continued use (AWAC 1996). Phosphorus is still being used because of uncertainties with regard to how humane it is relative to the other toxicants used to kill possums. Of the other toxicants, it has been generally perceived that 1080 and cyanide are acceptably humane and it has been suggested that anticoagulants cause little pain (Sadleir 1994). However, these assumptions are not based on good scientific data, and there is disagreement about the humaneness of 1080 (Osweileret al. 1985), and the anticoagulants (Kirkwood et al. 1994). The RSPCA in New Zealand is opposed to the use of any toxic agent that causes any animal to suffer and is particularly opposed to the use of phosphorus (Eason et al. 1994; Loague 1994).

Although some research has been done on the efficiency and welfare impacts of traps (Warburton 1992), before 1996 no research in New Zealand had focused on the relative humanity of different vertebrate pesticides. Last year we initiated a programme to assess the currently used toxicants from a welfare perspective. During the experimental phase of this research, we are recording detailed descriptions of the behaviour of captive possums after exposure to the pesticides registered for possum control. Data to be collected include changes in body weight, food and water intake, general appearance and condition of coat, eyes, and nose, posture of the animals, unusual vocalisation and changes in behaviour. Physiological and biochemical assessment techniques will be used to measure parameters such as heart rate, body temperature, and plasma cortisol concentrations. Similar studies have been conducted with traps as a basis for setting internationally agreed standards (Warburton 1992).

Species-specific differences in absorption, distribution, metabolism, excretion, and pathophysiological responses make it difficult to extrapolate data generated in other animals to possums (Williams 1974; Walker 1978; Rozman 1988). Hence, close observation of possums poisoned with each of these agents is the only accurate method of assessing their relative humanity in this species. The results of these experiments are being discussed with animal welfare and community groups so that vigorous peer review is obtained.

We are in the process of assessing the three older pesticides, cyanide, 1080, and phosphorus. Results to date are summarised in Table 1.

TABLE 1: A summary of the mean time to onset of clinical signs, the mean 
duration of key symptoms during sickness behaviour, and mean time to death (with range) in possums following ingestion of cyanide, 1080, and phosphorus baits.

\begin{tabular}{|c|c|c|c|}
\hline $\begin{array}{l}\text { Parameter } \\
\text { /Toxicant }\end{array}$ & Cyanide & 1080 & Phosphorus \\
\hline $\begin{array}{l}\text { Lag phase } \\
\text { (normal } \\
\text { behaviour) }\end{array}$ & 1 minute & $2+$ hours & 7 hours \\
\hline $\begin{array}{l}\text { Sickness } \\
\text { behaviour }\end{array}$ & $\begin{array}{l}\text { Stage 1 } \\
\text { Ataxia } \\
2 \text { minutes } \\
\text { Stage 2 } \\
\text { Recumbent } \\
\text { with intermittent } \\
\text { spasms } \\
3 \text { minutes } \\
\text { Stage } 3 \\
\text { Recumbent with } \\
\text { limited activity } \\
8 \text { minutes }\end{array}$ & $\begin{array}{l}\text { Stage } 1 \\
\text { Ataxia } \\
\text { sometimes recumbent, } \\
\text { occasional retching } \\
\text { and vomiting rare } \\
6 \text { hours } \\
\text { Stage } 2 \\
\text { Recumbent, some } \\
\text { vocalisation, spasms } \\
\text { and laboured breathing } \\
3.5 \text { hours }\end{array}$ & $\begin{array}{l}\text { Stage 1 } \\
\text { Repositioning } \\
\text { Regular reposition, } \\
\text { apparent discomfort, } \\
\text { regular retching } \\
\text { and vomiting } \\
10 \text { hours } \\
\text { Stage } 2 \\
\text { Recumbent with } \\
\text { intermittent } \\
\text { repositioningand } \\
\text { ataxia } \\
16 \text { hours }\end{array}$ \\
\hline Death & $\begin{array}{l}14 \text { minutes } \\
\text { range }=6 \text { to } 22 \\
\text { minutes } \\
n=23\end{array}$ & $\begin{array}{l}12 \text { hours } \\
\text { range }=6-18 \text { hours } \\
n=8\end{array}$ & $\begin{array}{l}33 \text { hours } \\
\text { range }=11^{1 / 2} \text { hours } \\
\mathrm{n}=9\end{array}$ \\
\hline
\end{tabular}

Although the results are preliminary, it is already apparent that cyanide is the most acceptable of the three toxicants investigated to date. Phosphorus produced the most prolonged time to death and the most pronounced and protracted sickness behaviour in possums. In addition, ingestion of phosphorus paste caused erosion of the lining of the stomach and duodenum. However, the clinical signs of phosphorus poisoning in possums were actually less severe and less prolonged than we expected. Nevertheless the time to death following 1080 exposure was half that of phosphorus, and 1080-dosed animals exhibited few overt signs of pain or distress.

We will complete the evaluation of these three traditional toxicants before beginning our assessment of cholecalciferol and the anticoagulants pindone, and brodifacoum. It is anticipated that this comparative database will be used to sustain the use of acceptable toxicants or hasten the deregulation of those which are considered inhumane.

\section{REGULATORY TOXICOLOGY}

In the United States, recent "data call-ins" have resulted in the requirement to provide an up-to-date regulatory toxicology database for 1080, cyanide and zinc phosphide. Unfortunately since the use of 1080 is currently restricted to a Livestock Protection Collar(LPC) in the United States, only a limited package of toxicology studies have been completed (Fagerstone et al. 1994). No such "data call-in" has been required for a vertebrate pesticide in New Zealand to date. If such a review was undertaken in New Zealand for 1080, it could reveal major data deficiencies. Our overseas competitors in the agricultural products markets could potentially make "political mileage" out of our widespread use of pesticides that are not supported by adequate (by 1990s standard) regulatory toxicology databases. 
A typical regulatory toxicology package should include relevant studies of:

- Acute toxicity - oral, dermal, inhalation

- Skin and eye irritation

- Skin sensitisation

- Mutagenicity

- Three-month rodent feeding studies

- Long-term rodent feeding (including carcinogenicity) studies

- Developmental toxicity (teratogenicity, reproductive toxicity) in rabbits/rats

- Metabolism and pharmacology

- Ecotoxicology/environmental toxicology

These type of data are used to assess risk from the pesticide (or other chemical) to human health and the environment. The process of risk assessment typically involves four steps. These have been described as hazard identification, exposure assessment, risk characterisation and risk estimation (Beasley 1996). In Beasley's (1996) review entitled "1080 overview of toxicology issues" he points out that human exposure to $1080 \mathrm{might}$ arise from drinking contaminated water, ingestion of toxic baits, or by inhalation of bait dust or contact with 1080 solution by pest control operators and bait manufacturers. There is also a small risk of contamination of water or food sources by aerially-sown 1080 baits. More extensive toxicological and environmental studies should be required for pesticides that are aerially broadcast (1080) or are handled in the field at high concentrations by pest control workers (1080) than those used solely in bait stations, such as cyanide, phosphorus, cholecalciferol, or pindone.

Evaluation and interpretation of toxicology data in New Zealand is generally in accordance with internationally accepted criteria such as specified by OECD, US EPA or WHO. Data presented must allow for the determination of acceptable chemical residues in food or water for human or animal consumption. The fundamental hypotheses that have underpinned the development of regulatory testing of pesticides to assess the risk to humans are listed below:

- Adverse effects caused by chemical substances in animals are usually the same as those induced in man.

- Adverse reactions in man can be predicted from the toxic effects observed in laboratory animals treated with chemicals.

- Administration of high doses improves the predictability of animal experiments.

- Comparison of the dose causing toxicity in animals and prediction of human exposure forms the basis for risk assessment.

Laboratory based regulatory toxicology studies allow for the characterisation of a chemical in terms of its potential to cause genetic mutations, foetal abnormalities, and target-organ toxicity, as well as defining No Observable Effect Levels (NOELs) on which drinking water standards are set. The NOELs are needed for setting rigorous acceptable daily intakes (ADI) which can form the basis for determining a Maximum Acceptable Value (MAV) in drinking water. In addition to meeting current international standards, with the introduction of ERMA, evaluation of toxicology data for pesticide registration in New Zealand may be expanded to include specific safeguards to protect native species, ecosystems and Maori values.

A battery of regulatory toxicology studies have already been completed in the USA to support the limited use of 1080 in the Livestock Protection Collar. This included 17 studies on product chemistry, six studies on wildlife hazards, and four studies on human health hazards. The results from most of these studies were summarised in the Science Workshop on 1080 held in Christchurch in December 1995 (Fagerstone et al. 1994) and the raw data from some of these studies have been forwarded to Landcare Research and the Agricultural Compounds Unit (ACU).

At a meeting coordinated by the NSSC for Tb/possum control in February 1996, it was agreed that, in order to bolster the regulatory toxicology database to support the continued use of 1080, New Zealand agencies should focus on those regulatory studies identified as being the most important from a scientific perspective, bearing in mind what we know about 1080 from the scientific literature spanning 50 years (Seawright and Eason 1994; Eisler 1996) (Table 2). 


\section{TABLE 2: Toxicology studies required to satisfy New Zealand's regulatory requirement.}

\begin{tabular}{|c|c|}
\hline $\begin{array}{l}\text { Study types required } \\
\text { for registration of a } \\
\text { new pesticide }\end{array}$ & Status of 1080 database \\
\hline Acute toxicity & $\begin{array}{l}\text { Extensive database in the literature (see Rammell } \\
\text { and Fleming 1978; Seawright and Eason 1994; } \\
\text { Eisler 1995) }\end{array}$ \\
\hline Skin and eye irritation & Completed (see Fagerstone et al. 1994$)$ \\
\hline Skin sensitisation & Completed (see Fagerstone et al. 1994) \\
\hline Mutagenicity studies* & Currently in progress \\
\hline Three-month feeding studies* & Currently in progress \\
\hline $\begin{array}{l}\text { Developmental toxicity* } \\
\text { (teratogenicity } \\
\text { reproductive toxicity) }\end{array}$ & Currently in progress \\
\hline $\begin{array}{l}\text { Metabolism/ } \\
\text { pharmacology studies }\end{array}$ & $\begin{array}{l}\text { Extensive published database } \\
\text { (see Eason } \text { et al. 1994) }\end{array}$ \\
\hline Environmental studies & $\begin{array}{l}\text { Extensive published database (see Parfitt et al. } \\
\text { 1994) but Good Laboratory Practice studies to EPA } \\
\text { specifications still not completed }\end{array}$ \\
\hline
\end{tabular}

$*=$ toxicology studies currently being undertaken under contract to AHB/DoC in the USA

The new toxicology studies listed in Table 2 are being conducted to assess risks to human health from 1080 exposure by extrapolation from animal data and will fill a significant data-gap. To date, 1080 has received the highest priority for re-evaluation from a regulatory toxicology perspective because of its high usage in comparison to the other compounds. Similar scrutiny focused on the other vertebrate pesticides used to kill possums could also reveal significant gaps in the toxicology database.

\section{CONCLUSION}

Market access barriers may be imposed on New Zealand if our pest control techniques are deemed unacceptable to overseas markets. The principles of 'product stewardship' must be applied to vertebrate pesticide products because of their toxicity to other mammals and their associated potential to do harm if used or handled inappropriately.

Control methods for possums must be demonstrated to be economic, effective, and most importantly, humane. If the toxicants used to kill possums are inhumane their use must be discontinued. Our current knowledge is incomplete as regards the relative humaneness of the products presently used for possum control. During the next 18 months we will generate a database which should support the continued use or deregistration of these toxicants.

Equally, the use of any pesticide should be underpinned by a comprehensive regulatory toxicology database which may need to be reviewed and updated. Most poisons research in New Zealand has focused on the environmental toxicology and nontarget impacts of pesticides used for possum control, with little attention given to studies required to satisfy other regulatory requirements. A series of investigations is currently underway to fill gaps in the database for 1080, including mutagenicity, teratogenicity and chronic feeding studies. In the future, we can anticipate that existing environmental toxicology, non-target impact, and regulatory toxicology studies may need to be supplemented by further ecotoxicology studies to OECD standards. Public perception will exert an increasing influence on the future of vertebrate pesticide use in New Zealand. Real community involvement in research and possum control is essential. Mechanisms for disseminating information have improved through the effort of the 
National Possum Control Agencies (NPCA), but continued effort to improve technology transfer and community involvement in pest control research, including the assessment of different techniques on the grounds of humaneness or cost-effectiveness, is required.

\section{ACKNOWLEDGEMENTS}

AGMARDT are thanked for their contribution to research on animal welfare and the preparation of this paper, Lynne Milne and Andrea Rhodes for assistance with the welfare experiments outlined, and the Department of Conservation and the Animal Health Board for their facilitation of additional regulatory studies on 1080.

\section{REFERENCES}

Agcarm Review 1995. Old times up for license tests.

Agcarm Review 1996. Old chemicals under the microscope.

AWAC 1994. Report of the Animal Welfare Advisory Committee on its work during 1993. p.8.

AWAC 1996. Animal Welfare Advisory Committee Annual Report. p.19.

Beasley, M., 1996. 1080-overview of toxicology issues. Pp 15-18. In: Improving Conventional Control of Possums. The Royal Society of New Zealand Miscellaneous Series 35 .

Colvin, B.A., Jackson, W.B. and Hegdal, P.L., 1991. Secondary poisoning hazards associated with rodenticide use. Proc. International Congress Plant Prot. 11: 6064.

Cowan, P.E., 1991. The ecological effects of possums on the New Zealand environment. Veterinary Continuing Education, Massey University, Publication No. 132: 7388.

Eason, C.T., Henderson, R., Thomas, M.D. and Frampton, C.M., 1994. The advantages and disadvantages of sodium monofluoroacetate and alternative toxins for possum control Pp 159-166. In: Seawright, A.A.; Eason, C.T. (Eds). Proceedings of the Science Workshop on 1080, The Royal Society of New Zealand, Miscellaneous Series 28.

Eason, C.T. and Spurr, E.B., 1995. Review of the toxicity and impacts of brodifacoum on non-target wildlife in New Zealand. N.Z. J. Zool. 22: 311-379.

Eisler, R., 1995. Sodium monofluoroacetate (1080) hazards to fish, wildlife and invertebrates: A synoptic review. US Department of the Interior. Biological Report \#27. 47p.

Fagerstone, K.A., Savarie, P.J., Elias, D.J. and Schafer, E.W., 1994. Recent regulatory requirements for pesticide registration and the status of compound 1080 studies conducted to meet EPA requirements. Pp. 33-39.In: Seawright, A.A.; Eason, C.T. $(E d s)$. Proceedings of the Science Workshop on 1080, The Royal Society of New Zealand, Miscellaneous Series 28.

Kirkwood, J.K., Sainsbury, A.W. and Bennett, I., 1994. The welfare of freeliving wild animals: Methods of assessment. Animal Welfare 3: 257-273.

Livingstone, P., 1994. The use of 1080 for control of animal pests. Pp 1-10. In: Seawright, A.A.; Eason, C.T.(Eds). Proceedings of the Science Workshop on 1080, The Royal Society of New Zealand, Miscellaneous Series 28.

Loague, P., 1994. An animal welfare perspective. Pp 109-113. In: Animal welfare in the twenty-first century: Ethical, educational, and scientific challenges. Proceedings of the conference held at the School of Medicine, Christchurch, New Zealand. ANZCCART.

MAF 1993. Animal Welfare in New Zealand. Published by Ministry of Agriculture and Fisheries. 16p.

MAF 1995. Strategic Directions to the Year 2000. Agriculture, horticulture, food. Published by Ministry of Agriculture and Fisheries. 24p.

Osweiler, G.D., Carson, T.L., Buck, W.B. and Van Gelder, G.A., 1985. Clinical and diagnostic veterinary toxicology. Kendall Hunt Publishing Company. 494p.

Rozman, K., 1988. Disposition of xenobiotics: species differences.Toxicologic Pathology 16(2): 123-129. 
Sadleir, R., 1994. Vertebrate pest control - a conservation perspective. Pp. 113-119.In: Animal Welfare in the twenty-first Century: Ethical, Education and Scientific Challenges. R.M. Baker, D.J. Mellor and A.M. Nicol (Eds.). Australia and New Zealand Council for the Care of Animals in Research and Teaching.

Seawright, A.A. and Eason, C.T., 1994. Proceedings of the Science Workshop on 1080. The Royal Society of New Zealand, Miscellaneous Series 28, 178p.

Spurr, E.B., 1994. Impacts on non-target invertebrate populations of aerial application of sodium monofluoroacetate (1080) for brushtail possum control. Pp. 116-123.In: Seawright, A.A. and Eason, C.T. (Eds.). Proceedings of the Science Workshop on 1080, The Royal Society of New Zealand, Miscellaneous Series 28.

Walker, C.H., 1978. Species differences in microsomal monooxygenase activity and their relationship to biological half lives. Drug Metabolism 7: 295-323.

Warburton, B., 1992. Victor foot-hold traps for catching Australian brushtailed possums in New Zealand: Capture efficiency and injuries. Wildlife Society Bulletin 20: 6773.

Weiler, E.D., Tayjock, M.A. and Greenley, D.E., 1993. Quality requirements for biocides in the 1990's. Quality Assurance; Good Practise, Regulation and Law 2: 244-250.

Williams, N., 1994. Food and fibre market implication. Pp 20-33.In: Seawright, A.A.; Eason, C.T. (Eds). Proceedings of the Science Workshop on 1080, The Royal Society of New Zealand, Miscellaneous Series 28.

Williams, R.T., 1974. Inter-species variation in the metabolism of xenobiotics.Biochemical Society Transactions 2: 339-377. 